a.ternating cinereous and blackish shades, the former predominating; one distinct black median line, preceded by a blackish shade. Beneath uniform cinereous gray, discal dots not prominent.

Hab. Massachusetts.

The beautiful cinereous and black coloration of this fine species wili at once separate it.

\title{
NOTES ON THE LIFE HISTORY OF THE AMERICAN TIGER MOTH.
}

BY ROBERT BUNKER, ROCHESTER, N.Y.

\section{Arctia Americana.}

Egg spherical, .04 inch in diameter, honey yellow, shiny and smooth as polished glass; laid in straight rows. Larva, when first hatched, oneeighth of an inch long, head small and black, budy dark brown clothed with ten longitudina rows of bunches of spreading hairs; dark brown on the sides, dark gray on the back. First moult somewhat increased in size, color unchanged. Second moult $3 / 8$ inch long, daris sooty brown; hair dark brown on the sides, grayish brown above. Third mouit $3 / 4$ inch long; hair on the sides and fore part above, reddish brown; light gray on the back.

Hybernated Sept. 16th. June 1st, 1875, fourth moult; 11/4 inches long; body blackish brown, sides and fore part above clothed with ochre yellow, black with long bluish gray hairs. Fifth mouit-body two inches long, velvety black, ornamented above with four rows of very long bluish gray hairs (directed backwards); in front and on the sides with dark yellowish-red hair, except the third row, which is made up of about equal parts of red and gray hairs; hairs immediately back of the head short and directed forward. Spiracles yellowish white, with a waxy lustre. Feet dark, snuff brown.

Cocoon thin and loosely put together, with hair from the body woven in. 
Three specimens of this rare species were captured here last season. The one that came into my possession was brought by a friend, and laid about fity esge wh? in the box. With all the care I could bes ow upon them only two reached maturity. A large majority perished during hybernation. Several sickened and died after the last moult; probably in a state of nature not more than two per cent. would reach the imago state.

\section{NOTES ON BUTTERFLIES.}

BY W. H. EDWARDS, COALBURGH, W. VA.

I am able to complete the history of $M$. phaeton, part of which I communicated to the CAN. ENT. in Jan'y, 1869, vol. 1, p. 59.

The eggs are laid in large ciusters of from 200 to 400 each, upon the under side of leaves of Chelone glabra. They are sub-conical, truncated, ribbed on upper half, yellow when laid, but soon turn to crimson. In 19 or 20 days, as Mr. Scudder informs me, they hatch. As tha eggs found by me (13th June) had been deposited some days, I could not verify that point. The young larvae at once begin to construc a web, usually on the topmost leaves of the stem, and feed on the green leaves enclosed; as these are consumed, the web is extended down the s'em, covering fresh leaves. The first moult takes place at six days, and the second at about the same time from the first. The third at a further interval of nine to ten days. Between the first and third the larvæ live much outside of the web, but the moult takes place within. Before the third moult a substantial web is constructed, and after the larvæ have passed this moult, they become lethargic, and so remain till early the following spring. This period of lethargy commences, at this place, about the 15th of July. The web last constructed is often upon a different plant from that on which the larvæ feed, and in nearly all cases is supported by adjoining stems being incorporated.

Wi:h the first watm days of April the larvæ leave the web and scatter about the swamp in search of the young stems of Chelone. They moult twice and reach maturity about the 5th of May. The chrysalis period is 